\title{
Faktor-Faktor yang Mempengaruhi Minat Petani dalam Menggunakan Pembiayaan As-Salam Pada Perbankan Syariah
}

\author{
Rista Suryadi ${ }^{1}$ dan Ayif Fathurrahman ${ }^{1}$
}

Abstrak: Penelitian ini bertujuan untuk menganalisis faktor-faktor yang mempengaruhi minat petani dalam menggunakan pembiayaan as-salam pada perbankan syariah. Penelitian ini merupakan penelitian deskriptif kualitatif dan kuantitatif. Jenis data yang digunakan adalah data primer yang berupa kuesioner dan wawancara kepada para petani di Desa Bangunjiwo, Kasihan, Bantul serta data sekunder berupa hasil kuesioner yang digunakan untuk menguji hipotesis. Variabel yang digunakan dalam penelitian ini adalah variabel pengetahuan, promosi, lokasi dan minat. Sampel yang digunakan dalam penelitian ini berjumlah 92 responden. Berdasarkan hasil penelitian, diperoleh hasil bahwa variabel pengetahuan, promosi dan lokasi berpengaruh positif dan signifikan terhadap minat petani dalam menggunakan pembiayaan as-salam pada perbankan syariah. Hal ini dikarenakan petani di Desa Bangunjiwo, Kasihan, Bantul tidak memiliki pengetahuan mengenai perbankan syariah dan pembiayaan as-salam, para petani tidak pernah mendapatkan sosialisasi maupun promosi dari perbankan syariah mengenai pembiayaan as-salam, serta jarak rumah tinggal dengan kantor perbankan syariah yang sangat jauh dan sulit untuk dijangkau.

Kata kunci: Perbankan Syariah; Petani; Pengetahuan; Promosi; Lokasi; Minat; AsSalam.

Suryadi, R., \& Fathurrahman, A. (2019). Faktor-Faktor yang Mempengaruhi Minat Petani dalam Menggunakan Pembiayaan As-Salam Pada Perbankan Syariah. Journal of Economics Research and Social Sciences, 3(1), 19-30.

\section{Pendahuluan}

Perbankan syariah adalah bentuk aplikasi dari ekonomi islam, yang mana dalam menjalankan kegiatan usaha ekonominya harus berdasarkan prinsip-prinsip syariah. Semua yang dilakukan dalam ekonomi Islam harus berdasarkan ikhlas antara pelaku ekonomi dan melarang adanya riba (unsur bunga), gharar (ketidakpastian), maisir (perjudian) dan kezaliman (Wiroso, 2011).

Saat ini perbankan syariah sedang mengalami perkembangan yang fluktuatif. Perkembangan jumlah kantor pada BUS (Bank Umum Syariah) meningkat dari 1745-unit pada tahun 2012 sampai tahun 2014 mencapai angka 2139 unit, kemudian menurun menjadi 1824-unit pada tahun 2018, sama halnya dengan UUS (Unit Usaha Syariah) yang juga menurun dari 517-unit pada tahun 2012 menjadi 346-unit di tahun 2018. Namun perkembangan jumlah kantor pada BPRS (Bank Pembiayaan Rakyat Syariah) cenderung meningkat, di mana pada tahun 2012 sebesar 401-unit menjadi 446-unit pada tahun 2018 (Otoritas Jasa Keuangan, 2018). 
Perkembangan fisik perbankan syariah yang fluktuatif ini tidak lantas membuat pembiayaan yang disediakan perbankan syariah juga ikut menurun. Seiring waktu berjalan, dengan semakin berkembangnya perbankan syariah, tingkat penyaluran pembiayaan justru semakin meningkat. Namun dari sekian produk perbankan syariah seperti mudharabah, murabahah, musyarakah, ijarah, istishna, qardh dan as-salam, hanya produk pembiayaan as-salam yang memiliki proporsi pembiayaan paling kecil. Pada Tabel 1 akan diperlihatkan betapa kecilnya proporsi penyaluran pembiayaan produk as-salam di Bank Umum Syariah dan Unit Usaha Syariah.

Tabel 1 Komposisi Pembiayaan yang Diberikan Bank Umum Syariah dan Unit Usaha Syariah (Dalam Miliar Rupiah)

\begin{tabular}{lccccc}
\multicolumn{1}{c}{ Akad } & 2012 & 2013 & 2014 & 2015 & 2016 \\
\hline Mudharabah & 12.023 & 13.625 & 13.802 & 14.906 & 14.577 \\
Musyarakah & 18.96 & 39.874 & 42.83 & 54.033 & 66.68 \\
Murabahah & 56.365 & 110.565 & 112.228 & 117.777 & 125.478 \\
Akad Salam & 0 & 0 & 0 & 0 & 0 \\
Akad Istishna' & 376 & 582 & 588 & 678 & 821 \\
Akad ljarah & 7.345 & 10.481 & 10.319 & 11.561 & 18.248 \\
Akad Qardh & 12.09 & 8.995 & 8.057 & 4.938 & 3.774 \\
Total & 107.159 & 184.122 & 187.824 & 203.893 & $\mathbf{2 2 9 . 5 7 8}$ \\
\hline
\end{tabular}

Sumber: Otoritas Jasa Keuangan, 2016

Berdasarkan data pada Tabel 1, terlihat jelas bahwa komposisi pembiayaan yang diberikan oleh perbankan syariah dari tahun ke tahun selalu mengalami kenaikan yang cukup signifikan, namun untuk pembiayaan as-salam dari tahun 2012 sampai tahun 2016 selalu Rp 0 komposisi pembiayaannya. Pembiayaan as-salam itu sendiri merupakan akad jual beli barang pesanan (muslam fiih) antara penjual (muslam illaihi) dan pembeli (al-muslam) dengan pembayaran pada saat akad telah disepakati dan sesuai dengan syarat yang berlaku, kemudian barang tersebut di kirim kemudian hari oleh penjual. Selain itu, pembiayaan as-salam pada perbankan syariah lebih diutamakan untuk pembiayaan sektor pertanian (PAPSI, 2003).

Tidak adanya komposisi pembiayaan as-salam pada BUS dan UUS, serta proporsi pembiayaan yang sangat rendah pada BPRS, membuktikan bahwa akad as-salam sebenarnya ada secara teoritis, namun dalam praktiknya masih belum optimal. Padahal melalui akad as-salam, perbankan syariah dapat menginvestasikan dananya pada sektor pertanian. Sehingga, melalui akad as-salam petani akan mendapatkan dana di muka untuk membeli bibit, pupuk dan membayar pekerja serta kebutuhan lain yang diperlukan untuk menumbuhkan hasil pertanian. Selain itu, melalui pembiayaan assalam yang berlandaskan prinsip syariah ini dapat membantu para petani yang mengalami kesulitan akses permodalan untuk mengelola pertaniannya, sehingga melalui akad as-salam ini sesungguhnya dapat mengatasi dan mengurangi salah satu penyebab kemiskinan di Indonesia (Ogunbado, Ahmed, \& Abubakar, 2015). 
Kabupaten Bantul sebenarnya memiliki potensi pertanian yang sangat besar. Pada tahun 2017 dengan 50.058 hektar luas Kabupaten Bantul, 55 persen atau 27.876 hektar diantaranya adalah lahan pertanian (BPS Bantul, 2018). Namun, berdasarkan luas lahan pertanian Kabupaten Bantul tersebut, banyak Kecamatan yang ketersediaan lahan pertaniannya semakin berkurang dan menyempit seiring dengan perkembangan dan pertumbuhan tata wilayah yang berupa pemukiman penduduk dan fasilitas umum. Selain itu, lahan berkurang juga disebabkan oleh beberapa petani yang menjual lahan pertaniannya untuk pembangunan karena kesulitan dalam pendanaan produksi pertanian, salah satu contohnya adalah Kecamatan Kasihan. Dalam Kecamatan Kasihan, terdapat Desa Bangunjiwo yang luas lahan pertaniannya hanya tinggal 191,62 hektar dari luas wilayah Desa Bangunjiwo sebesar 1.543,43 hektar. Hal ini membuat Desa Bangunjiwo masuk kedalam kriteria desa rawan pangan (Demapan, 2015).

Berdasarkan latar belakang diatas, maka tulisan ini akan mengkaji bagaimana urgensi penerapan pembiayaan akad as-salam di bidang pertanian, karena jika dilihat dari komposisi pembiayaannya itu masih sangat sedikit bahkan tidak ada. Selain itu, melalui penelitian ini akan mengungkap bagaimana pengaruh variabel pengetahuan, promosi, dan lokasi terhadap minat para petani di Desa Bangunjiwo, Kecamatan Kasihan, Kabupaten Bantul ini dalam menggunakan pembiayaan as-salam.

\section{Tinjauan Pustaka}

Penelitian tentang penerapan akad salam di Indonesia yang dilakukan oleh Widiana dan Annisa (2017), mereka menjelaskan bahwa akad salam memiliki potensi yang sangat strategis terhadap pengembangan bidang pertanian. Namun faktanya tidak adanya lembaga pembiayaan khusus untuk pertanian sehingga berimplikasi pada sulitnya petani mendapatkan modal untuk mengembangkan pertaniannya. Selama ini pembiayaan pertanian diserahkan saja pada bank umum dengan program kredit berbasis bunga yang disubsidi pemerintah, namun untuk mengakses pembiayaan tersebut memiliki persyaratan yang sangat ketat dan kehati-hatian yang tinggi karena sektor pertanian sangat beresiko tinggi. Dampaknya, ketika gagal panen maka petani tidak mampu mengembalikan pinjaman tersebut dan dapat terjebak dalam jeratan hutang yang semakin membengkak. Sehingga perlu sekali bank syariah hadir di tengah petani menawarkan pembiayaan salam sebagai pembiayaan alternatif yang aman dan adil. Namun lembaga keuangan syariah juga harus memiliki strategi khusus dalam mensosialisasikan produk pembiayaan salam agar petani mengerti dan beralih kepada pembiayaan salam yang sesuai dengan prinsip syariah, sehingga proporsi pembiayaan salam perbankan syariah di Indonesia semakin meningkat.

Dalam hal pembiayaan salam, Roziq, Hisyamudin, Wahyuni, dan Purnamawati (2014) menemukan bahwa tidak ada pembiayaan salam yang ditemukan pada lembaga keuangan syariah khusus untuk petani singkong, pengusaha tempe, keripik singkong, dan tepung ubi kayu. Hal ini membuat petani singkong kebingungan dalam mendapatkan akses permodalan, karena lembaga keuangan syariah merasa kesulitan 
ketika memasarkan produk pertanian singkong setelah panen, rendahnya kualitas singkong saat musim hujan, dan besarnya resiko gagal panen. Selain itu juga, lembaga keuangan syariah kekurangan modal untuk membayar di muka, resiko kerugian modal yang besar, dan petani cenderung memiliki moral hazard untuk menjual kepada pihak lain ketika harga komoditas pertanian tersebut sedang menguat.

Sedangkan dalam penelitian Qusthoniah (2016), ia menganalisis kritis akad salam di perbankan syariah menjelaskan bahwa Bay' as salam biasanya digunakan oleh petani sebagai pembiayaan jangka waktu pendek sekitar 2-6 bulan. Jangka waktu pembiayaan relatif pendek karena yang dibeli oleh bank adalah barang seperti padi, palawija, dan cabai sehingga bank tidak berniat untuk menyimpannya sebagai inventory, maka dari itu bank cenderung mengunakan akad salam paralel, misalnya kepada pedagang di pasar, bulog, dan tengkulak. Namun sejauh ini skema pembiayaan salam masih belum banyak diterapkan oleh perbankan syariah dan produk yang ditawarkan masih berkisar pada musyarakah, murabahah, mudharabah dan ijarah, sehingga proporsi pembiayaan salam $0,00 \%$. Salah satu strategi untuk mengembangkan perbankan syariah dapat dengan melakukan inovasi produk sehingga produk perbankan syariah tidak terkesan monoton, dan pihak perbankan syariah mesti bertindak tanggap dalam menghadapi kebutuhan masyarakat, karena jika tidak maka bank syariah akan terasing dibandingkan bank konvensional lainnya.

Penelitian mengenai prospek pembiayaan syariah pada sektor pertanian yang dilakukan oleh Ashari dan Saptana (2005) mengungkapkan bahwa salah satu permasalahan dalam pembangunan sektor pertanian adalah lemahnya permodalan. Meskipun pemerintah sudah mengeluarkan kredit program sektor pertanian, namun hasilnya masih kurang memuaskan bahkan menimbulkan masalah baru seperti membengkaknya hutang petani serta kredit macet. Lembaga keuangan syariah cukup prospektif untuk dijadikan alternatif modal dalam pertanian, serta perbankan syariah juga memiliki komitmen kuat untuk membiayai sektor riil sehingga dapat menjadi peluang besar bagi sektor pertanian.

Penelitian yang dilakukan oleh Ridhwan, Aziz, dan Yusoff (2014) yang menyatakan bahwa resiko dan ketidakpastian melekat dalam proyek-proyek pertanian dan rantai pasokan komoditas. Mengingat besarnya resiko, para petani, pengusaha pertanian, lembaga internasional, dan lembaga perbankan semakin mencari strategi dan pendekatan yang efektif dan berkelanjutan untuk mengurangi dan mengatasi resiko yang melekat tersebut. Terdapat beberapa resiko yang dihadapi oleh pengusaha pertanian dan mengharuskan mereka membiayai proyek mereka menggunakan produk pembiayaan dari perbankan syariah. Dari penelitian ini, menunjukkan bahwa mayoritas responden bersedia untuk melanjutkan proyek pertanian mereka meskipun mereka menghadapi resiko dan faham mengenai keuntungan dan kerugian dari resiko tersebut. Selain itu, lembaga keuangan syariah harus mempertimbangkan risiko-risiko dalam menyediakan dana moneter kepada para pengusaha pertanian untuk memastikan dana tersebut dapat mengatasi kerugian dan mendukung pengembangan proyek-proyek pertanian tersebut. 
Menurut Amin, Ghazali, dan Supinah (2010), variabel sikap dan norma subjektif berpengaruh positif terhadap penerimaan pembiayaan qardhul hasan, maka semakin tinggi sikap dan norma subjektif nasabah, maka akan semakin tinggi pula penerimaan nasabah terhadap pembiayaan qardhul hasan. Sedangkan variabel harga dalam pembiayaan qardhul hasan berpengaruh negatif terhadap pembiayaan qardhul hasan, maka semakin rendah harga pembiayaan qardhul hasan akan membuat semakin tinggi penerimaan nasabah terhadap pembiayaan qardhul hasan. Sehingga dapat disimpulkan bahwa niat petani menggunakan produk perbankan syariah dipengaruhi oleh sikap dan norma subjektif dari petani tersebut.

Penelitian yang dilakukan oleh Ridhwan dan Yusoff (2013) memfokuskan penelitiannya terhadap risiko yang dihadapi petani dalam pembiayaan pertanian yaitu meliputi risiko bisnis dan risiko finansial. Yang menjadi perhatian pada penelitian ini adalah bahwa petani mungkin tidak memiliki informasi maupun data untuk memperkirakan seberapa besar risiko yang akan dihadapi. Adapun strategi untuk mengurangi risiko tersebut yaitu dengan mendiversifikasi pemasaran dan rencana produksi, memberikan asuransi formal, memasarkan koperasi produk hasil pertanian, melakukan kontrak masa depan dengan harga, serta melakukan pembiayaan di luar ekuitas.

Penelitian yang dilakukan oleh Mohd Shafiai, dan Moi (2015) mencoba mengungkap bagaimana sektor pertanian dalam memandang akad yang ada pada perbankan syariah merupakan pembiayaan yang fleksibel bagi sektor pertanian. Adapun petani di Malaysia cenderung mengkonsumsi sendiri hasil pertanian mereka dan tidak pernah menghitung tabungan serta pendapatan bulanan mereka. Selain itu, petani Malaysia banyak yang terjerat hutang yang berkepanjangan sehingga perbankan syariah ataupun lembaga keuangan syariah di Malaysia harus mempertimbangkan elemen hutang dalam kehidupan petani agar tidak terjadi hal yang tidak diinginkan.

Adapun perbedaan antara penelitian yang dilakukan oleh peneliti sekarang dengan penelitian terdahulu yaitu terletak pada variabel bebas dan variabel terikatnya. Pada penelitian ini, peneliti menggunakan variabel bebas atau variabel independen diantaranya yaitu variabel pengetahuan, promosi, dan lokasi, sedangkan untuk variabel terikat atau variabel dependen adalah minat. Lokasi penelitian ini dilakukan di Desa Bangunjiwo, Kasihan, Bantul yang mayoritas penduduknya bekerja sebagai petani dan desa tersebut merupakan wilayah yang memiliki area sawah paling luas di Kecamatan Kasihan, Kabupaten Bantul. Peneliti menggunakan metode wawancara dan kuesioner untuk mendapatkan informasi dari petani mengenai minat mereka dalam menggunakan pembiayaan as-salam pada perbankan syariah. Selain itu, pada penelitian terdahulu masih sangat jarang yang melakukan penelitian dengan studi kasus petani pada sebuah desa, sehingga peneliti ingin mencoba meneliti minat para petani di Desa Bangunjiwo, Kasihan, Bantul dalam menggunakan pembiayaan as-salam pada perbankan syariah. 


\section{Metode Penelitian}

Metode penelitian yang digunakan dalam penelitian ini merupakan penelitian eksploratif dengan menggunakan pendekatan deskriptif kualitatif dan kuantitatif. Jenis data yang digunakan dalam penelitian ini adalah data primer dan data sekunder yang berupa kuesioner dan wawancara. Objek dalam penelitian ini adalah Desa Bangunjiwo, Kasihan, Bantul. Subjek dari penelitian ini adalah masyarakat yang berprofesi sebagai petani. Teknik pengambilan sampel yang digunakan dalam penelitian ini menggunakan teknik purposive sampling atau mengambil sampel berdasarkan tujuan tertentu untuk menggali informasi berdasarkan fenomena yang terjadi di lapangan.

Adapun dalam menentukan jumlah sampel, peneliti menggunakan metode Taro Yamane (Yamane, 1967) untuk menghitung jumlah sampel yang diperlukan. Berdasarkan jumlah populasi petani di Desa Bangunjiwo, maka diperoleh jumlah sampel yang akan digunakan sebagai responden oleh peneliti yang dihitung menggunakan metode Taro Yamane dengan tingkat signifikansi $90 \%$ adalah 92 responden.

\section{Hasil dan Pembahasan}

Sebelum melakukan pengujian lebih lanjut, penulis perlu melakukan beberapa tahap pengujian untuk membuktikan apakah data yang terkumpul dapat digunakan. Uji yang pertama adalah Uji Validitas, uji ini dilakukan untuk memastikan bahwa informasi yang diperoleh melalui penyebaran kuesioner yang dilakukan oleh peneliti merupakan informasi yang akurat (Basuki \& Prawoto, 2016). Berdasarkan hasil Uji Validitas yang telah dilakukan, didapatkan data bahwa nilai korelasi antar variabel dengan nilai totalnya lebih dari 0,25 atau diatas 0,05 sehingga seluruh butir pertanyaan variabel pada kuesioner dapat dikatakan valid, sehingga dapat digunakan untuk analisis selanjutnya.

Uji selanjutnya yang perlu dilakukan adalah Uji Reliabilitas, instrumen penelitian dapat dikatakan reliabel apabila digunakan untuk mengukur obyek yang sama sehingga menghasilkan data yang sama pula. Uji Reliabilitas ini menggunakan Alpha Cronbach sebagai tolok ukurnya. Berdasarkan hasil uji reliabilitas ini, nilai Alpha Cronbach setiap variabel diatas 0,70 . Hal ini berarti instrumen penelitian yang digunakan dalam penelitian ini tidak menimbulkan anti ganda dan data yang dihasilkan konsisten, sehingga dapat dikatakan bahwa item variabel pengetahuan, promosi, lokasi dan minat ini memiliki reliabilitas tinggi (Basuki \& Prawoto, 2016).

Untuk Uji Normalitas dalam penelitian ini menggunakan fungsi distributif kumulatif dengan menggunakan nilai pada Kolmogorov-Smirnov. Model dapat dikatakan berdistribusi normal ketika nilai signifikansi > nilai apha (Suliyanto, 2011). Berdasarkan hasil pengujian normalitas dalam penelitian ini, nilai signifikansinya adalah 0,301 atau lebih besar dari 0,05. Dari hasil Uji Normalitas tersebut, dapat dikatakan bahwa penelitian ini berdistribusi normal. 
Untuk melihat varian persebaran data, perlu dilakukan Uji Heteroskedastisitas (Basuki dan Prawoto, 2016). Berdasarkan hasil Uji Heteroskedastisitas, nilai signifikansi variabel pengetahuan adalah sebesar 0,445, nilai signifikansi variabel promosi sebesar 0,344 dan nilai signifikansi variabel lokasi adalah sebesar 0,457. Berdasarkan nilai signifikansi tersebut, dapat dikatakan bahwa model tidak mengandung penyakit heteroskedastisitas karena semua nilai signifikansinya lebih besar dari pada alpha $(0,05)$.

Fungsi uji multikolinearitas digunakan untuk melihat ada tidaknya korelasi antar variabel. Model regresi ini dapat dikatakan bebas dari penyakit multikolinearitas ketika nilai Variance Inflation Factor (VIF) kurang dari 10 dan dikuatkan dengan nilai Tolerance lebih dari 0,01 (Suliyanto, 2011). Berdasarkan hasil uji multikolinearitas, variabel pengetahuan, promosi dan lokasi memiliki nilai Tolerance diatas 0,01 dan nilai VIF kurang dari 10, sehingga dapat dikatakan bahwa variabel pengetahuan, promosi dan lokasi bebas dari penyakit multikolinearitas.

Uji hipotesis secara simultan ini digunakan untuk mengetahui pengaruh variabel pengetahuan, promosi dan lokasi terhadap kurangnya minat petani dalam menggunakan pembiayaan as-salam pada perbankan syariah dengan melihat nilai signifikansinya.

Tabel 2 Hasil Uji Hipotesis secara Simultan

\begin{tabular}{lccccc}
\hline \multicolumn{1}{c}{ Model } & Sum of Squares & df & Mean Square & F & Sig. \\
\hline Regression & 166,087 & 3 & 55,362 & 201,177 &, 000 \\
Residual & 24,217 & 88 & & & \\
Total & 190,304 & 91 & 275 & & \\
\hline
\end{tabular}

Sumber: Data diolah

Berdasarkan hasil uji hipotesis secara simultan, nilai signifikansi dari variabel bebas adalah 0,000 atau $<0,05$ sehingga dapat disimpulkan bahwa variabel pengetahuan, promosi dan lokasi secara simultan berpengaruh terhadap variabel minat. Uji hipotesis secara parsial ini dilakukan untuk melihat pengaruh dari variabel pengetahuan, promosi dan lokasi terhadap variabel minat. Berdasarkan hasil uji-t, didapatkan hasil sebagai berikut:

Tabel 3 Hasil Uji Hipotesis secara Parsial

\begin{tabular}{lccc}
\multicolumn{1}{c}{ Variabel } & Unstd Coefficients B & Std Coefficients & Sig \\
\hline Pengetahuan & 0,837 & 0,424 & 0,000 \\
Promosi & 0,891 & 0,496 & 0,000 \\
Lokasi & 0,876 & 0,928 & 0,000 \\
\hline
\end{tabular}

Sumber: Data diolah

Berdasarkan hasil uji-t di atas, dapat disimpulkan bahwa variabel pengetahuan, promosi dan lokasi berpengaruh signifikan terhadap minat Uji R-square (Koefisien Determinasi). Pengujian R-square atau biasa disebut koefisien determinasi yang mana digunakan untuk melihat seberapa besar pengaruh dari seluruh variabel independen yaitu meliputi 
variabel pengetahuan, promosi dan lokasi terhadap variabel dependen yaitu kurangnya minat masyarakat menggunakan pembiayaan as-salam pada perbankan syariah.

Tabel 4 Hasil Uji R-square

\begin{tabular}{ccc}
$\mathbf{R}$ & $\mathbf{R}$ Square & Adj $\mathbf{R}$ Square \\
\hline 0,934 & 0,873 & 0,868 \\
\hline
\end{tabular}

Sumber: Data diolah

Berdasarkan hasil pengujian R-square atau koefisien determinasi di atas, karena model pengujian ini merupakan regresi linier berganda, maka dapat diketahui bahwa nilai Adjusted $R$ Square adalah 0,868. Dengan nilai Adjusted $R$ Square 0,868, artinya variabel independen (variabel pengetahuan, promosi dan lokasi) dapat menjelaskan variabel dependen (minat petani menggunakan pembiayaan as-salam pada perbankan syariah) sebesar 86,8 persen, sedangkan 13,2 persen sisanya dijelaskan oleh variabel lain di luar model.

Berdasarkan hasil penelitian menunjukkan bahwa faktor pengetahuan berpengaruh positif dan signifikan terhadap minat petani dalam menggunakan pembiayaan as-salam pada perbankan syariah. Pengetahuan itu sendiri merupakan semua informasi yang dimiliki oleh petani khususnya mengenai perbankan syariah beserta produk-produk pembiayaan perbankan syariah. Berdasarkan hasil penelitian pada kuesioner, menunjukkan bahwa pengetahuan petani mengenai perbankan syariah dan pembiayaan as-salam masih sangat kurang. Hal berikut senada dengan hasil penelitian Mohd Shafiai, dan Moi (2015) yang mencoba mengungkap bahwa pembiayaan as-salam merupakan produk perbankan syariah yang fleksibel bagi sektor pertanian, sehingga harus dimaksimalkan penggunaan pembiayaannya.

Selain itu juga, para petani tidak mengetahui sama sekali mengenai perbankan syariah serta pembiayaan as-salam. Berdasarkan paparan Sudaryanto selaku Ketua Kelompok Tani Mulyo, para petani juga tidak mengerti mengenai produk-produk yang ditawarkan oleh perbankan syariah, sehingga mereka lebih memilih menggunakan modal pribadi yang mereka miliki (Wawancara Petani, 26 November 2018).

Kendala yang mereka hadapi adalah ketika mereka tidak memiliki cadangan uang dan memiliki kebutuhan yang sangat mendesak, sehingga terpaksa meminjam kepada keluarga atau kerabat terdekat untuk mengelola lahan pertanian mereka. Hal tersebut dilakukan karena petani takut untuk berurusan atau meminjam pada pihak perbankan, karena ketika mereka mengalami gagal panen, mereka takut tidak dapat mengembalikan pinjaman yang mereka ajukan. Maka dari itu, mayoritas petani di Desa Bangunjiwo, Kasihan, Bantul lebih memilih menggunakan modal sendiri karena mereka merasa lebih aman dan tidak merasa memiliki tanggungan hutang (Sudaryanto, Wawancara Petani, 26 November 2018).

Hasil penelitian menunjukkan bahwa faktor promosi berpengaruh positif dan signifikan terhadap minat petani dalam menggunakan pembiayaan as-salam pada perbankan 
syariah. Perbankan syariah yang memiliki produk pembiayaan yang unggul serta memiliki manfaat yang besar, promosi merupakan strategi utama dan paling penting untuk kemajuan dari perbankan syariah itu sendiri. Dalam promosi, juga harus diperhatikan kualitas dari produk pembiayaan tersebut. Produk pembiayaan yang ditawarkan harus dapat menjawab permasalahan yang dialami oleh nasabah khususnya petani dalam hal pendanaan. Kualitas produk tidak hanya mengenai manfaat namun juga meliputi skema pembiayaan yang sederhana dan mudah difahami oleh petani, agar tujuan utama promosi dapat tercapai.

Selain itu, dengan pangsa pasar yang mulai terhimpit oleh perbankan konvensional, maka perbankan syariah harus dapat menghadapi tantangan serta ancaman dengan memperkenalkan dan mempromosikan produk-produk pembiayaannya kepada masyarakat luas. Perbankan syariah juga dapat bersinergi dengan pemerintah pusat ataupun daerah untuk membantu sosialisasi, promosi serta edukasi petani agar faham mengenai produk pembiayaan yang ada pada perbankan syariah. Hal ini dikarenakan pihak perbankan syariah tidak pernah memberikan sosialisasi atau mempromosikan produk pembiayaan syariah yang mereka miliki sehingga banyak petani yang tidak mengerti bahwa ada pembiayaan yang cocok untuk usaha sektor pertanian.

Berdasarkan hasil penelitian yang sudah dilakukan, maka dapat disimpulkan bahwa promosi sangat berpengaruh terhadap minat petani dalam menggunakan pembiayaan as-salam, karena strategi mempromosikan suatu produk merupakan misi penting yang harus dilakukan oleh perbankan syariah untuk meningkatkan minat petani dalam menggunakan pembiayaan as-salam pada perbankan syariah.

Berdasarkan hasil penelitian yang telah dilakukan, didapatkan hasil bahwa faktor lokasi berpengaruh terhadap minat petani dalam menggunakan pembiayaan as-salam pada perbankan syariah. Menurut Kotler (2002), lokasi merupakan salah satu kunci sukses sebuah usaha. Hal tersebut dikarenakan lokasi memiliki pengaruh terhadap keputusan nasabah atau petani dalam menggunakan pembiayaan as-salam pada perbankan syariah. Kebanyakan petani kurang tertarik menggunakan pembiayaan as-salam pada perbankan syariah karena lokasi dan jarak kantor perbankan syariah dengan tempat tinggal sangat jauh dan memerlukan biaya akomodasi dan transport yang tidak sedikit untuk menjangkau dan mengakses perbankan syariah.

Menurut Pujo (Wawancara Petani, 27 November 2018) jarak antara rumah petani dengan kantor perbankan syariah yang ada di Kasihan maupun di Bantul itu relatif jauh, kurang lebih di atas $15 \mathrm{Km}$. Jika para petani menggunakan motor pribadi kurang lebih di atas 30 menit untuk mencapai lokasi kantor perbankan syariah, sedangkan jika menggunakan angkutan umum akan menjadi lebih lama. Selain iu, rumah para petani terletak di ujung Desa Bangunjiwo dan jarang sekali ada angkutan umum yang melintas. Hal tersebut yang membuat para petani kurang minat untuk menggunakan pembiayaan di perbankan syariah khususnya pembiayaan as-salam. 
Penentuan lokasi kantor perbankan syariah merupakan kebijakan yang sangat penting, karena kantor yang terletak di lokasi yang strategis akan sangat memudahkan nasabah dalam hal urusan dengan perbankan. Seperti halnya dekat dengan pasar, dekat dengan desa, dekat dengan perumahan, dekat dengan perkantoran dan industri.

Berdasarkan hasil penelitian yang telah dilakukan oleh peneliti, maka dapat disimpulkan bahwa dalam menentukan lokasi kantor harus sangat diperhatikan oleh perbankan syariah karena akan berdampak pada perkembangan dan kemajuan perbankan syariah itu sendiri. Selain itu juga, faktor lokasi akan meningkatkan minat petani untuk menggunakan pembiayaan as-salam pada perbankan syariah. Hal ini dikarenakan sejatinya, pembiayaan as-salam merupakan pembiayaan yang sangat sesuai untuk usaha sektor pertanian dan dapat memutus rantai kemiskinan dikalangan petani.

Ketika petani menggunakan pembiayaan as-salam, resiko kegagalan akan semakin menurun ketika diiringi dengan peningkatan kualitas sumber daya manusia dari pihak bank yang faham mengenai seluk beluk pertanian, sehingga kualitas dan kuantitas dari hasil pertanian juga akan semakin baik dan meningkat sehingga sektor pertanian akan semakin sejahtera dan produksi hasil pertanian seperti beras, kedelai, jagung, sayuran, dan lain-lain akan semakin meningkat sehingga dapat mensuplai kebutuhan domestik, bahkan ketika produksi pertanian surplus maka dapat diekspor sehingga dapat meningkatkan pendapatan nasional. Selain meningkatkan pendapatan nasional, melalui pembiayaan as-salam akan meningkatkan pendapatan petani sehingga petani akan semakin sejahtera dan Indonesia tidak perlu lagi mengimpor kebutuhan pangan pokok dari luar negeri.

\section{Kesimpulan}

Variabel pengetahuan berpengaruh positif dan signifikan terhadap minat petani dalam menggunakan pembiayaan as-salam pada perbankan syariah. Namun, petani di Desa Bangunjiwo, Kasihan, Bantul masih sangat minim pengetahuan tentang pembiayaan assalam pada perbankan syariah sehingga belum menggunakan pembiayaan as-salam pada perbankan syariah.

Variabel promosi berpengaruh positif dan signifikan terhadap minat petani dalam menggunakan pembiayaan as-salam pada perbankan syariah. Perbankan syariah yang memiliki produk pembiayaan yang unggul serta memiliki manfaat yang besar, promosi merupakan strategi utama dan paling penting untuk kemajuan dari perbankan syariah itu sendiri. Petani di Desa Bangunjiwo, Kasihan, Bantul menegaskan bahwa pihak perbankan syariah tidak pernah memberikan sosialisasi atau mempromosikan pembiayaan as-salam sehingga banyak petani yang tidak mengerti bahwa ada pembiayaan syariah yang cocok untuk usaha sektor pertanian.

Variabel lokasi berpengaruh positif dan signifikan terhadap minat petani dalam menggunakan pembiayaan as-salam pada perbankan syariah. Lokasi kantor perbankan 
syariah dengan tempat tinggal yang jauh, membuat petani di Desa Bangunjiwo, Kasihan, Bantul kurang tertarik menggunakan pembiayaan as-salam pada perbankan syariah karena selain jauh, juga memerlukan biaya akomodasi dan transport yang tidak sedikit untuk menjangkau dan mengakses perbankan syariah.

\section{Daftar Pustaka}

Amin, H., Ghazali, M. F., \& Supinah, R. (2010). Determinants of Qardhul Hassan Financing Acceptance Among Malaysian Bank Customers : An Empirical Analysis. International Journal of Business and Society. 11(1), 1-16. Diakses dari http://www.ijbs.unimas.my/index.php/content-abstract/all-issues/30-vol-11-no-12010/134-determinants-of-qardhul-hassan-financing-acceptance-among-malaysianbank-customers-an-empirical-analysis

Ashari., \& Saptana. (2005). Prospek Pembiayaan Syariah untuk Sektor Pertanian. Pusat Analisis Sosial Ekonomi dan Kebijakan Pertanian, 23(2), 132-147. http://dx.doi.org/10.21082/fae.v23n2.2005.132-147

Badan Pusat Statistik Bantul. (2018), Bantul Dalam Angka. Diakses dari http://bantulkab.bps.go.id

Basuki, A. T., \& Prawoto, N. (2016). Analisis Regresi dalam Penelitian Ekonomi dan Bisnis. Depok: Raja Grafindo Persada.

Demapan. (2015). Desa Mandiri Pangan Bangunjiwo, Bantul. Diakses dari http://bangunjiwo-bantul.desa.id/index.php/first/artikel/32

Kotler, P. (2002). Manajemen Pemasaran, Edisi Milenium, Prebalindo: Jakarta.

Mohd Shafiai, M. H., \& Moi, M. R. (2015). Financial Problem among Farmer in Malaysia: Islamic Agricultural Finance as a Possible Solution. Asian Social Science, 11(4), 1-16. https://doi.org/10.5539/ass.v11n4p1

Ogunbado, A. F., Ahmed, U., \& Abubakar, Y. (2015). Islamic Banking and Finance in Nigeria: Exploration of Opportunities and Challenges. Journal of Islamic Economics Banking and Finance, 11(4), 102-112. Diakses dari https://www.researchgate.net/publication/319553479 Islamic Banking and Finan ce in Nigeria Exploration of its_Opportunities and Challenges

Otoritas Jasa Keuangan, 2018, Statistik Perbankan Syariah. Diakses dari www.ojk.go.id/id/kanal/syariah/data-dan-statistik/statistik-perbankan-syariah

Otoritas Jasa Keuangan. (2016). Statistik Perbankan Syariah. Diakses dari www.oik.go.id/id/kanal/syariah/data-dan-statistik/statistik-perbankan-syariah

PAPSI. (2003). Panduan Akuntansi Perbankan Syariab Indonesia. Cetakan 1, Jakarta : Ikatan Akuntan Indonesia.

Qusthoniah. (2016). Analisis Kritis Akad Salam di Perbankan Syariah. Jumal Syariah Universitas Islam Indragiri, 5(1), 1-20. https://doi.org/10.32520/.v5i1.55

Ridhwan, M., Aziz, A., \& Yusoff, M. M. (2013). Financing for Agro Projects in Islamic Banks. International Conference on Agriculture and Biotechnology. 60, 14-18. http://doi.org/10.7763/IPCBEE

Roziq, A., Hisyamudin, N., Wahyuni, M. I., \& Purnamawati, I. (2014). Model pembiayaan salam pada petani singkong dan usaha kecil berbahan singkong di kabupaten Jember. Jurnal Akuntansi Fakultas Ekonomi Universitas Jember, 12(1), 43-57. https://doi.org/10.19184/jauj.v12i2.1410

Sudaryanto. (2018). Wawancara Petani, 26 November 2018. 
Suliyanto. (2011). Ekonometrika Terapan-Teori dan Aplikasi dengan SPSS, Yogyakarta: CV Andi Offset.

Widiana., \& Annisa, A. A. (2017). Menilik Urgensi Penerapan Pembiayaan Akad Salam pada Bidang Pertanian di Lembaga Keuangan Syariah di Indonesia. Jurnal Ekonomi dan Perbankan Syariah. 8(2), 88-101. https://doi.org/10.18326/muqtasid.v8i2.88-101

Wiroso. (2011). Produk Perbankan Syariah, Edisi 1, Cetakan 1, LPFE Usakti, Jakarta.

Yamane. T. (1967). Elementary Sampling Theory. Englewood Cliffs. New Jersey : Prentice-Hall, Inc. 